\title{
Sport and public policy in Romania. Case study: Timisoara
}

\author{
Delia Nadolu
}

Department of Sociology, West University of Timișoara, Romania

\section{abstract}

The inclusion of physical activities in the weekly routine is undoubtedly a necessary condition for a healthy life. In order for sport to become a habit, it is necessary not only to have an adequate and diversified infrastructure, but also to be valued as such in the personal lifestyle.

TIn this article we analyse a series of official data regarding the non-practice of sports activities in Romania (EVS 2017), compared to the European situation (EHIS \& ESPA 2014), with a focus on the case study of Timisoara. The expectation of the youth form Timisoara youth (2013), The Strategy for the Youth of the Timisoara Municipality (2014-2019) and the attitude toward physical activities from Public Opinion Barometers in Timisoara (2016 and 2019) were analysed comparatively.

Key words: physical activity, health, public policy, public opinion.

\section{article details}

Article statistics: Word count: 1,616; Tables: 2; Figures: 4; References: 15

Received: June 2020; Accepted: August 2020; Published: November 2020

Full-text PDF: http://www.balticsportscience.com

Copyright @ Gdansk University of Physical Education and Sport, Poland

Indexation: Celdes, Clarivate Analytics Emerging Sources Citation Index (ESCl), CNKI Scholar (China National Knowledge Infrastructure), CNPIEC, De Gruyter - IBR (International Bibliography of Reviews of Scholarly Literature in the Humanities and Social Sciences), De Gruyter - IBZ (International Bibliography of Periodical Literature in the Humanities and Social Sciences), DOAJ, EBSCO - Central \& Eastern European Academic Source, EBSCO - SPORTDiscus, EBSCO Discovery Service, Google Scholar, Index Copernicus, J-Gate, Naviga (Softweco, Primo Central (ExLibris), ProQuest - Family Health, ProQuest - Health \& Medical Complete, ProQuest - Illustrata: Health Sciences, ProQuest - Nursing \& Allied Health Source, Summon (Serials Solutions/ProQuest, TDOne (TDNet), Ulrich's Periodicals Directory/ulrichsweb, WorldCat (OCLC)

Funding: This research received no specific grant from any funding agency in the public, commercial, or not-for-profit sectors. Author has declared that no competing interest exists.

Dr Delia Nadolu, Timisoara 300223, Bd.V.Parvan, no.4, room 333, Romania; phone +40 592233; e-mail: delia. nadolu@e-uvt.ro

Open Access License: This is an open access article distributed under the terms of the Creative Commons Attribution-Non-Commercial-NoDerivatives 4.0 International (https://creativecommons.org/licenses/by-nc-nd/4.0/), which permits use, distribution and reproduction in any medium, provided the original work is properly cited, the use is non-commercial and is otherwise in compliance with the license. 


\section{INTRODUCTION}

Physical activity is a major condition for a health life and an improved wellbeing, and this is not any more a simple statement but also a very consistent domain for the public policies almost all over the world. Encouragement of the population to practice various physical activities, investment into dedicated facilities, proper education about a healthy lifestyle represent nowadays subjects into the public discourses in all developed countries. The White Paper on Sport [1] represents one of the first EU documents that address the issue of physical activity as public policies, defined on three strategic dimensions: the social role of sport, the economic dimension of sport and the organisation of sport. The main objectives related to sport and societies include "to encourage physical and mental fitness and to fight obesity through participation in regular physical activity".

According to Eurostat statistics [2-4], Romania has had the lowest rate in the EU of weekly practicing sport, fitness or recreational physical activities with only $7.5 \%$ in 2014 , as compared with almost $80 \%$ in Denmark and Finland. With a similar approach, the Eurobarometer for Sport and Physical Activity [5] from the same year (2014) shows that $60 \%$ of the Romanian's population does not practice any kind of physical activity. The main reasons for not practicing physical activity are the lack of interest (30.3\%) and the lack of facilities in the neighbourhood (20.7\%) [6].

In recent worldwide statistics, the Health World Organisation shows that one out of four adults does not practice any kind of physical activity, and in almost half of all countries, there are public policies toward physical activity. In the Global Action Plan for the Prevention and Control of Non-Communicable Diseases 2013-2020, one of the main targets is to decrease the number of the population that does not practice enough physical activity by $10 \%$ [7]. In Romania, the Ministry of Youth and Sport has elaborated the National Strategy for Sport 2016-2032 [8] with an assumed mission defined by three dimensions: a) to increase the degree of active participation of the population of all ages in permanent sports activities in the interest of raising and maintaining the level of individual health, improving the degree of cohesion, integration and social trust; b) to increase the degree of practicing sports activities, especially among children and young people in order to train and develop active, educated and responsible citizens; c) to increase the level and quality of Romania's representation at the highest performance sports competitions.

The more recent statistics reflect yet a positive impact. The results from the Romanian sample for the European Values Survey from 2018 [9] reflect a quite similar situation with 2014 (Figure 1):

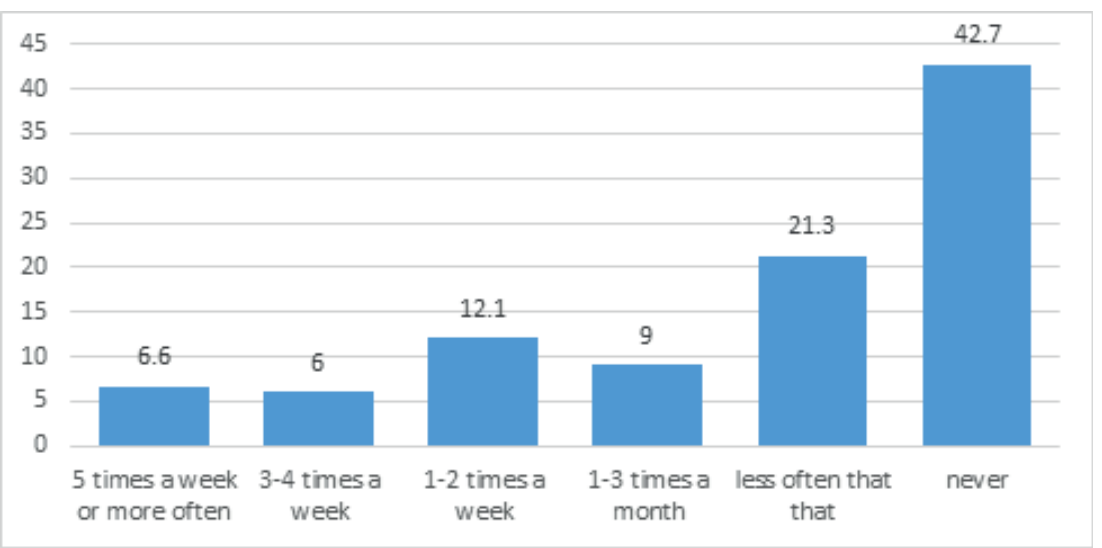

Fig. 1. Q: How often do you exercise or do sports? (Romanian EVS database) (\%) 
Of course, if we are going into a detailed analysis, the participation in physical activities decreases with age (Table 1).

Table 1. Q: How often do you exercise or do sports, breakdown by age? (Romanian EVS database) (\%)

\begin{tabular}{lccc} 
& $18-39$ years & $40-59$ years & $60+$ \\
\hline 5 times a week or more often & 8.9 & 5.6 & 4.8 \\
3-4 times a week & 10.3 & 4.5 & 2 \\
$1-2$ times a week & 20.8 & 8.9 & 4.4 \\
$1-3$ times a month & 13.6 & 7.9 & 4.2 \\
less often that that & 21.7 & 24.1 & 17.2 \\
never & 22.2 & 47.3 & 64.6 \\
no answer & 2.4 & 1.7 & 2.6 \\
\hline Total & $100 \%$ & $100 \%$ & $100 \%$ \\
\hline
\end{tabular}

On the other hand, when looking at the national statistics, the evolution of sport fields at schools has recorded an ascendant evolution (Figure 2) [10].

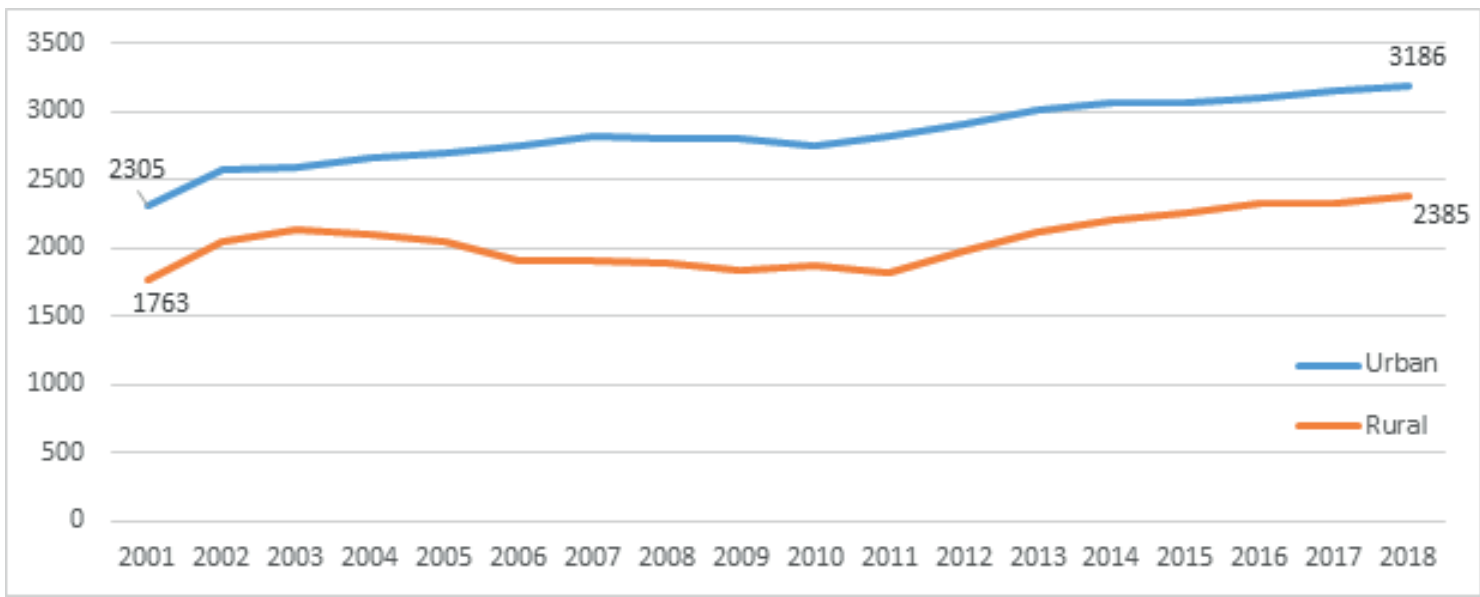

Fig. 2. The evolution of sport fields at schools (source: National Statistics)

Thus, what can be done to improve sport participation in Romania? Is it an issue of mentality with a low level for interest, an issue of education with a lack of knowledge about the benefit of physical activity or an issue of infrastructure with too few facilities to practice sport? An adequate answer will be searched by focusing on the case study of the city of Timisoara, one of the five biggest cities in Romania.

\section{MATERIAL AND METHODS}

To answer the research question, a comparative analysis was conducted between several official data and sociological surveys focused on involving the population from Timisoara in physical activity. Thus, the first set of data that approach this subject was collected from a large sociological survey made in 2014 to elaborate the Youth Strategy in the city. Another data come from public opinion barometers made in 2016 and 2019 on a representative sample of the population of Timisoara that include this kind of items. Finally, another data come from the municipality budget and local investments in sport facilities. 


\section{RESULTS}

In the project, Give voice to your generation, the Intercultural Institute of Timisoara coordinated sociological research as support for the elaboration of the Youth Strategy for the City of Timisoara and implicitly local public policies for young people [11]. Thus in November-December 2013, 940 questionnaires were distributed among subjects aged between 14 and 35 from Timisoara. The error limit was $+/-3.19 \%$. The subjects were selected based on two variables: age (14-19 years, 20-24 years, 25-29 years and 3035 years) and occupation (pupil/student and outside of the formal education system). According to these data, young people from Timisoara in 2014 preferred to spend their free time in the city mostly during the weekend (50\%) and only $30 \%$ went out twice or three times weekly. The most preferred way of spending free time was going out with friends (44\%). Practicing sport was mentioned only by $13 \%$ and outdoor activities (walking, park, excursions) by $22 \%$ of the young population from Timisoara. Concerning the improvement in leisure facilities, one-third of the youth rom Timisoara requested from the City Hall thematic parks for outdoor activities (33\%).

Based on the entire output of this research, the Youth Strategy of the Timisoara City Hall 2014-2020 was elaborated. It included a distinct dimension dedicated to sport with two main objectives (D5.1 Promoting the practice of sport among all young people and D5.2 Establishment of infrastructure dedicated to table sports at the level of each neighbourhood), and twelve strategic measures that define the local public policy for this domain:

- M30. Organizing sports events addressed to different categories of young people (by neighbourhoods, age groups, sports, etc.), as well as supporting local sports clubs.

- M31. Creation of a HUB / activity centre for sports clubs for young people

- M32. Local amateur sports competitions (table sports)

- M33. Establishment of a park with ramps for skateboards, rollers and bikers

- M34. Establishment / development / support of basketball courts

- M36. Establishment / development / support of football pitches

- M37. Establishment / development / support of tennis courts

- M38. Establishment / development / support of ice rinks (indoor)

- M39. Establishment / development / maintenance of indoor swimming pools

- M40. Establishment / development / support of running tracks

- M41. Establishment / development / support of velodrome

- M42. Location of sports equipment for adults in the parks of Timisoara (outdoor fitness)

During the period of 2014-2020 several investments were included in the municipality budget (Table 2) [12].

Even though the Polyvalent Hall of the Polytechnic University represents the main investment in sport of the Timisoara City Hall (the mayor is a professor and a former rector of the Polytechnic University), there are several investments in sport made by the City Hall. All these main investments cumulate more than 10 million euros for seven years, and this, at a yearly budget of 300 million euros, represents around $0.5 \%$. Of course, it is better than nothing, even if without an adequate budget it is difficult to sustain a dedicated public policy for sport.

What is the public opinion about sport facilities in Timisoara? The results of sociological surveys $(2016,2019)$ coordinated by the Department of Sociology from West University of Timisoara show a trend of improving general public satisfaction related to the issue of physical activities (Figure 3) [13, 14]. 
Table 2. Main investments in sport by municipality budget 2014-2020 in Euros at an average yearly exchange rate $^{1}$ (Timisoara City Hall)

\begin{tabular}{|c|c|c|c|c|c|c|c|}
\hline $\begin{array}{l}\text { Main investments } \\
\text { in sport }\end{array}$ & 2014 & 2015 & 2016 & 2017 & 2018 & 2019 & 2020 \\
\hline $\begin{array}{l}\text { Polyvalent Hall of the } \\
\text { Polytechnic University }\end{array}$ & $2,024,929$ & $2,609,674$ & $1,469,671$ & 328,364 & 214,892 & 421,479 & 627,812 \\
\hline $\begin{array}{l}\text { Constantin Jude Sport } \\
\text { Hall }\end{array}$ & 157,494 & & & 29,990 & 25,572 & 63,643 & \\
\hline Skate-park- & 112,496 & & & 153,236 & & & \\
\hline $\begin{array}{l}\text { Semi-Olympic } \\
\text { swimming pool }\end{array}$ & & 44,994 & 111,339 & & & & \\
\hline $\begin{array}{l}\text { New stadium with } \\
42,000 \text { seats }\end{array}$ & & 67,492 & 44,535 & & & & \\
\hline $\begin{array}{l}\text { Multipurpose hall with } \\
15,000 \text { seats }\end{array}$ & & 67,492 & 44,535 & & 85,957 & & \\
\hline Synthetic surface rink & & & & 8,975 & & & \\
\hline Bega Sports Complex & & & & 18,607 & & 82,272 & \\
\hline $\begin{array}{l}\text { Sports complexes in } \\
\text { neighbourhoods }\end{array}$ & & & & 262,691 & 373,912 & 463,626 & 418,541 \\
\hline Aqua park & & & & & 21,489 & & \\
\hline
\end{tabular}

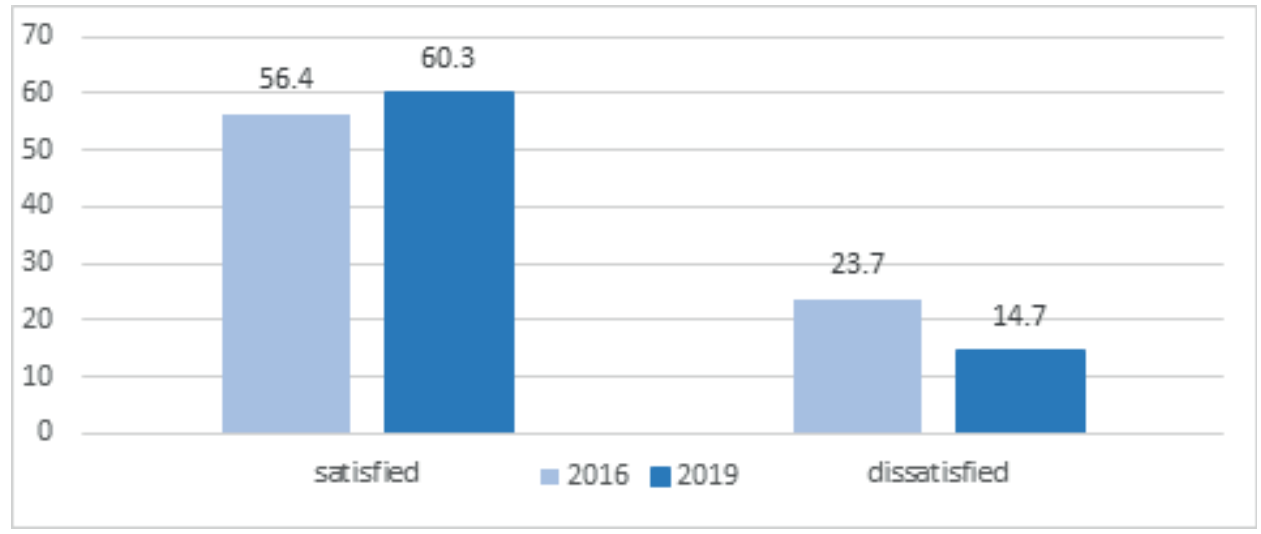

Fig. 3. Q: How satisfied are you with sports facilities in Timisoara? (POB 2016, 2019) (\%)

During only three years, almost $10 \%$ of the population of Timisoara are not any more dissatisfied with the sport facilities that exist now in the city, as a direct result of municipality and private investments. Even with that, practicing physical activity in 2019 was below the national level (Figure 4).

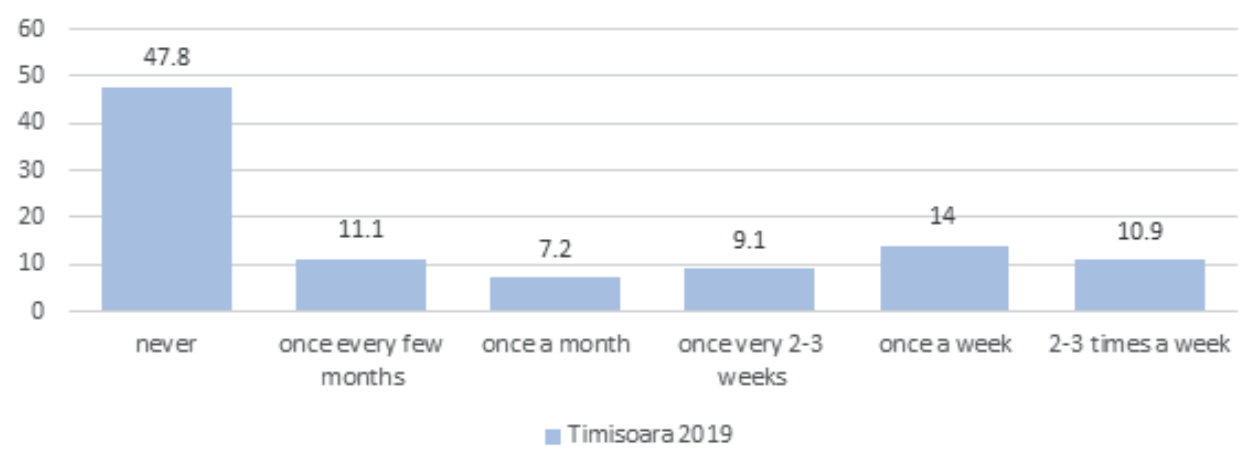

Fig. 4. Q: In the last 12 months, how often have you practiced sport personally? (\%)

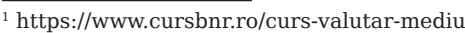


This distribution has a significant positive correlation with education $(0.089, \mathrm{p}<0.001)$ and with family income $(0.157, \mathrm{p}<0.001)$ and a significant negative correlation with age $(-0.460, \mathrm{p}<0.001)$.

\section{CONSLUSIONS}

In the context where the Youth Strategy was elaborated on the basis of young population's expectations, and in the context where the City Hall has made some investments in sport facilities, confirmed by a fairly high level of population satisfaction, it is quite paradoxical that the amount of population that does not practice physical activity in Timisoara is below the national level. One possible answer to this situation is that the mentality, with a real interest in physical activity, not as fashion but as very consistent personal habit for wellbeing. To obtain this value, formal and non-formal socialization is the best approach [15].

\section{REFERENCES}

[1] Commission of the European Communities. White Paper on Sport (white paper). Brussels: COM 391 final; 2007. [Available at https://eur-lex.europa.eu/legal-content/EN/TXT/HTML/?uri=LEGISSUM:135010\&from=EN].

[2] Sport and Physical Activity (Special Eurobarometer 412). Brussels: European Commission; 2014. [Available at https:// ec.europa.eu/commfrontoffice/publicopinion/archives/ebs/ebs_412_en.pdf].

[3] Eurostat. Sport Statistics 2018 edition. [Available at https://ec.europa.eu/eurostat/documents/4031688/8716412/ KS-07-17-123-EN-N.pdf/908e0e7f-a416-48a9-8fb7-d874f4950f57].

[4] European Commission. Sport and Societies. [Available at https://ec.europa.eu/sport/policy/society_en]

[5] Eurostat. European Health Interview Survey (EHIS) [Available at https://ec.europa.eu/eurostat/web/microdata/european-health-interview-survey].

[6] Eurostat. Reasons of non-participation in cultural or sport activities [Available at https://ec.europa.eu/eurostat/web/ products-datasets/-/ilc scp06].

[7] World Health Organization. Global action plan for the prevention and control of noncommunicable diseases 20132020; 2013

[8] Ministry of Youth and Sports (Romania). Strategia nationala pentru sport 2016-2032 [The National Strategy for Sport 2016-2032]. Bucharest, Romania; 2016. Romanian. [Available at http://mts.ro/wp-content/uploads/2016/02/ Strategia-nationala-pentru-SPORT-v2016-v2.pdf].

[9] First Public Release of the Romanian EVS/WVS 2017/2018 data. The Romanian Group for the Study of the Social Values [Available at http://www.romanianvalues.ro/in-the-news/firstpublicreleaseoftheromanianevswvs20172018data].

[10] National Statistics Institute (Romania). Sport fields in school. [Available at www.insse.ro]. [Accessed on March 2020].

[11] The Strategy for the Youth of the Timisoara Municipality 2014-2020. [Available at https://www.primariatm.ro/uploads/domino/atasamente_hcl/6B9E8CC890FCC451C2257D770020DAB8/Anexa.pdf].

[12] Timisoara Municipality Budget [Available at https://www.primariatm.ro/index.php?meniuId=2\&viewCat=26] [Accessed on February 2020].

[13] Matichescu M, editor. Barometrul de opinie publica asupra calitatii vietii in Municipiul Timisoara [The Public Opinion Barometer on the Quality of Life in Timisoara]. Timisoara: West University Publishing House; 2018. Romanian.

[14] Matichescu M, editor. Partial analysis of the Public Opinion Barometer research. Timisoara: unpublished paper; 2020.

[15] Turcu MD, Todor R. Socialization through sport. Effects of physical education and sport. The Annals of "Stefan cel Mare" University, Suceava. 2010;3(2). 